\title{
Focus on cardiac arrest
}

\author{
Alain Cariou ${ }^{1,2,3^{*}}$, Antoine Vieillard-Baron ${ }^{4,5}$ and Anders Aneman ${ }^{6}$
}

๑ 2016 Springer-Verlag Berlin Heidelberg and ESICM

\section{Outcome}

Cardiac arrest (CA) survival rates vary substantially, which may reflect differences in quality of the local chain of survival for both out-of-hospital and in-hospital cardiac arrest (OHCA and IHCA). A recent large, prospective, population-based registry conducted over 2 years in Paris, France, found a $7.5 \%$ survival rate at discharge after OHCA [1] (Fig. 1), whereas a $10.8 \%$ 30-day survival rate was reported from the Danish National Registry [2]. A recent analysis of the American Heart Association Get with the Guidelines-Resuscitation registry, including 358 hospitals between 2000 and 2009, documented a $18.8 \%$ (IQR 14.5-22.6 \%) median survival rate to hospital discharge following IHCA [3]. A similar survival rate (18.4\%) was reported by the UK National Cardiac Arrest Audit database [4]. Survival rates are widely variable in IHCA patients, depending on the location and circumstances, even for patients in intensive care units as illustrated by recent reports $[5,6]$. The use of a prediction model in the emergency department could facilitate the identification of patients with a higher mortality risk [7] to guide preventive interventions.

\section{Post-resuscitation care}

The importance of post-CA management is reflected by the substantial increase in clinical studies in recent years published in critical care journals. Health authorities and ethics committees ensure that the principles of ethical conduct of research involving human subjects are fulfilled, despite the time constraints and urgency inherent to $\mathrm{CA}$ and resuscitation, giving adequate opportunities for research [8].

The European Resuscitation Council (ERC) collaborated for the first time with the European Society of Intensive Care Medicine (ESICM) in 2015 to produce

\footnotetext{
*Correspondence: alain.cariou@cch.aphp.fr

1 AP-HP, Medical Intensive Care Unit, Cochin Hospital, 27 Rue du

Faubourg Saint-Jacques, 75679 Paris Cedex 14, France

Full author information is available at the end of the article
}

updated European post-resuscitation care guidelines [9, 10]. Changes in guidelines included a greater emphasis on the need for targeted temperature management (TTM) [11] that still seemed to be missing in almost half of CA patients according to pragmatic registry data [1]. The use of TTM at $33{ }^{\circ} \mathrm{C}$ was seriously challenged by the results of the landmark TTM Trial [12] and subsequent substudies. In a post hoc analysis of patients with moderate shock on admission after OHCA, TTM at $33{ }^{\circ} \mathrm{C}$ compared to $36^{\circ} \mathrm{C}$ did not significantly influence 180 -day mortality but was associated with increased levels of lactate and need for increased vasopressor support [13]. As it is difficult to discern which patients may further benefit from one or other temperature level, the ERC-ESICM 2015 guidelines acknowledge that there is now an option to target a temperature of $36^{\circ} \mathrm{C}$ instead of the previously recommended $32-34{ }^{\circ} \mathrm{C}$. The optimal time to start TTM is also challenged. Prehospital induction of hypothermia using cold fluids did not improve survival or neurological status among patients resuscitated from OHCA. Intraarrest induction of hypothermia did not confer any additional benefit as compared with hypothermia started at hospital arrival as judged by biological markers of inflammation or brain damage as well as clinical outcome in OHCA patients [14]. While these studies were performed irrespective of shockable or non-shockable initial cardiac rhythms, the importance of this issue remains debatable.

The ERC-ESICM 2015 guidelines also highlighted the importance of early coronary angiogram and recommended that an early coronary angiogram (CAG) be performed in patients with ECG criteria for ST segment elevation myocardial infarction (STEMI), including left bundle branch block. Among patients without STEMI criteria, the best approach regarding coronary angiogram remains unclear. A TTM Trial post hoc analysis of patients without acute ST elevation found no difference in survival or neurological outcome between patients who did or did not receive an early CAG within $6 \mathrm{~h}$ of arrest, even after adjustment using a propensity score analysis [15]. In contrast, in a large cohort study in which

\section{Springer}




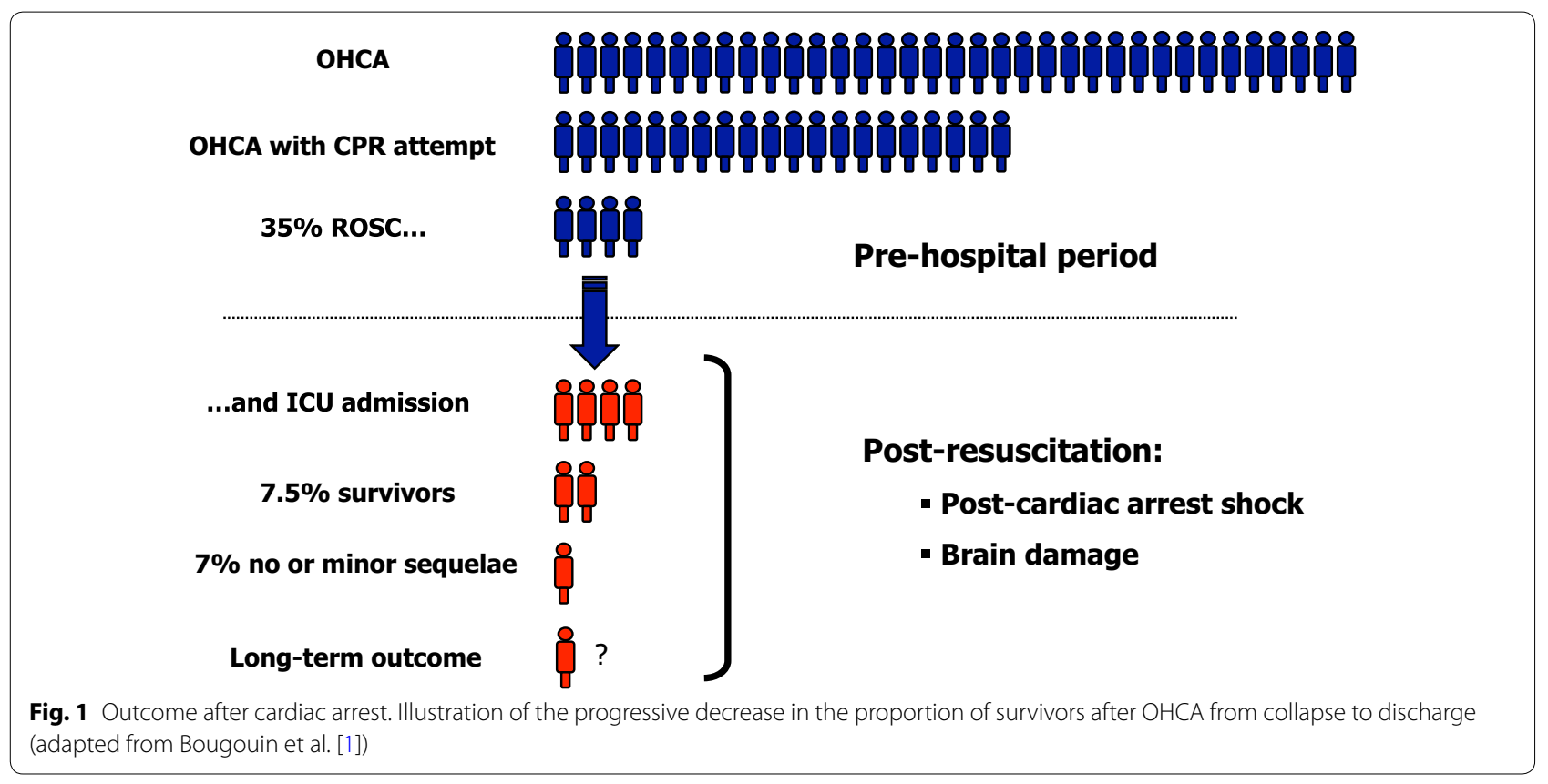

a systematic and immediate CAG was performed in all non-STEMI patients, emergent percutaneous coronary intervention in nearly one-third of the population was independently associated with an improved hospital outcome [16]. Several ongoing studies are investigating the potential benefits associated with an early invasive strategy in selected population of post-CA patients (DISCO study, NCT 02309151; PEARL study, NCT 02387398).

Regarding ventilatory post-resuscitation management, the ERC-ESICM 2015 guidelines recommend to titrate the inspired oxygen concentration to maintain the arterial blood oxygen saturation in the range of 94-98\%. Severe hyperoxia (>300 $\mathrm{mmHg}$ ) over the first $24 \mathrm{~h}$ was associated with decreased survival to discharge in 184 OHCA patients admitted to ICU [17], similar to previous observational studies. Metabolic derangements occurring in the first hours and days after resuscitation may also increase the risk for detrimental neurological outcome. In 381 patients resuscitated following OHCA, an increased blood glucose level over the first $48 \mathrm{~h}$ was an independent predictor of poor outcome (cerebral performance category 3-5) [18]. A strategy combining both control of glycemia and minimization of glycemic variations is suggested to improve post-resuscitation outcomes.

\section{Prognostication}

Early identification of patients with no chance of a good neurological recovery after CA is necessary to avoid inappropriate treatment and to inform relatives. Members of the ERC and the Trauma and Emergency Medicine
Section of the ESICM have provided an advisory statement on neurological prognostication in comatose survivors of cardiac arrest [19]. Following review of 73 studies, the quality of evidence was found to be low or very low for almost all studies. The role of clinical examination was emphasized. In patients still comatose with absent or extensor motor response at $72 \mathrm{~h}$ post-CA, with any TTM, bilateral absence of pupillary and corneal reflexes and early status myoclonus were identified as robust predictors. A multimodal approach, including the pivotal role of electrophysiology examination, was highlighted. The loss of N20 wave of short-latency somatosensory evoked potentials was identified as the most robust predictor of unfavorable outcome, while unreactive malignant EEG patterns after rewarming were also a strong predictor. In a recent cohort study of 54 comatose CA patients, suppression-burst at any time over the first $72 \mathrm{~h}$ indicated a poor prognosis, with a $0 \%$ false positive rate (FPR) (95\% confidence interval (CI) 0-10\%); all patients with suppression-burst or a low voltage $(<20 \mu \mathrm{V})$ EEG at $24 \mathrm{~h}$ had a poor outcome, with an FPR of $0 \%$ (95 \% CI $0-8 \%$ [20]. All these modalities help to identify that the comatose CA survivor has a poor prognosis [21].

In conclusion, there is a growing body of published clinical studies to guide cardiac arrest management, post-resuscitation care, and prognostication that will undoubtedly increase further.

Author details

${ }^{1}$ AP-HP, Medical Intensive Care Unit, Cochin Hospital, 27 Rue du Faubourg Saint-Jacques, 75679 Paris Cedex 14, France. ${ }^{2}$ Paris Descartes University, 15, 
Rue de l'Ecole de Médecine, 75270 Paris Cedex 06, France. ${ }^{3}$ INSERM U970 (Team 4), Paris, France. ${ }^{4}$ Section Thorax-Vascular Disease-Abdomen-Metabolism, Intensive Care Unit, University Hospital Ambroise Paré, Assistance Publique-Hôpitaux de Paris, 92100 Boulogne-Billancourt, France. ${ }^{5}$ INSERM U-1018, CESP, Team 5 (EpReC, Renal and Cardiovascular Epidemiology), UVSQ, 94807 Villejuif, France. ${ }^{6}$ Intensive Care Unit, Liverpool Hospital, South Western Sydney Local Health District, University of New South Wales, South Western Sydney Clinical School, Ingham Institute for Applied Medical Research, New South Wales, Australia.

Received: 15 May 2016 Accepted: 17 May 2016 Published online: 1 June 2016

\section{References}

1. Bougouin W, Lamhaut L, Marijon E, Jost D, Dumas F, Deye N, Beganton F, Empana JP, Chazelle E, Cariou A, Jouven X (2014) Characteristics and prognosis of sudden cardiac death in Greater Paris: population-based approach from the Paris Sudden Death Expertise Center (Paris-SDEC). Intensive Care Med 40:846-854

2. Wissenberg M, Lippert FK, Folke F, Weeke P, Hansen CM, Christensen EF, Jans H, Hansen PA, Lang-Jensen T, Olesen JB, Lindhardsen J, Fosbol EL, Nielsen SL, Gislason GH, Kober L, Torp-Pedersen C (2013) Association of national initiatives to improve cardiac arrest management with rates of bystander intervention and patient survival after out-of-hospital cardiac arrest. JAMA 310:1377-1384

3. Girotra S, Nallamothu BK, Spertus JA, Li Y, Krumholz HM, Chan PS, American Heart Association Get with the Guidelines-Resuscitation Investigators (2012) Trends in survival after in-hospital cardiac arrest. N Engl J Med 367:1912-1920

4. Nolan JP, Soar J, Smith GB, Gwinnutt C, Parrott F, Power S, Harrison DA, Nixon E, Rowan K, National Cardiac Arrest Audit (2014) Incidence and outcome of in-hospital cardiac arrest in the United Kingdom National Cardiac Arrest Audit. Resuscitation 85:987-992

5. Al-Alwan A, Ehlenbach WJ, Menon PR, Young MP, Stapleton RD (2014) Cardiopulmonary resuscitation among mechanically ventilated patients. Intensive Care Med 40:556-563

6. Efendijev I, Raj R, Reinikainen M, Hoppu S, Skrifvars MB (2014) Temporal trends in cardiac arrest incidence and outcome in Finnish intensive care units from 2003 to 2013. Intensive Care Med 40:1853-1861

7. Coslovsky M, Takala J, Exadaktylos AK, Martinolli L, MerzTM (2015) A clinical prediction model to identify patients at high risk of death in the emergency department. Intensive Care Med 41:1029-1036

8. Petriş AO, Cimpoeşu DC, Ungureanu D (2015) What's new in ethics of cardio-pulmonary resuscitation research: too little time and too many rules? Intensive Care Med 41:120-122

9. Nolan JP, Soar J, Cariou A, Cronberg T, Moulaert VR, Deakin CD, Bottiger BW, Friberg H, Sunde K, Sandroni C (2015) European Resuscitation Council and European Society of Intensive Care Medicine 2015 guidelines for post-resuscitation care. Intensive Care Med 41:2039-2056

10. Nolan JP, Soar J, Cariou A, Cronberg T, Moulaert VR, Deakin CD, Bottiger BW, Friberg H, Sunde K, Sandroni C (2016) Erratum to: European Resuscitation Council and European Society of Intensive Care Medicine 2015 guidelines for post-resuscitation care. Intensive Care Med 42:488-489
11. Cariou A, Nolan JP, Sunde K (2015) Ten strategies to increase survival of cardiac arrest patients. Intensive Care Med 41:1820-1823

12. Nielsen N, Wetterslev J, Cronberg T, Erlinge D, Gasche Y, Hassager C, Horn J, Hovdenes J, Kjaergaard J, Kuiper M, Pellis T, Stammet P, Wanscher M, Wise MP, Åneman A, Al-Subaie N, Boesgaard S, Bro-Jeppesen J, Brunetti I, Bugge JF, Hingston CD, Juffermans NP, Koopmans M, Køber L, Langørgen J, Lilja G, Møller JE, Rundgren M, Rylander C, Smid O, Werer C, Winkel P, Friberg H, TTM Trial Investigators (2013) Targeted temperature management at $33^{\circ} \mathrm{C}$ versus $36^{\circ} \mathrm{C}$ after cardiac arrest. N Engl J Med 369:2197-2206

13. Annborn M, Bro-Jeppesen J, Nielsen N, Ullén S, Kjaergaard J, Hassager C, Wanscher M, Hovdenes J, Pellis T, Pelosi P, Wise MP, Cronberg T, Erlinge D, Friberg H, TTM Trial Investigators (2014) The association of targeted temperature management at 33 and $36^{\circ} \mathrm{C}$ with outcome in patients with moderate shock on admission after out-of-hospital cardiac arrest: a post hoc analysis of the Target Temperature Management trial. Intensive Care Med 40:1210-1219

14. Debaty G, Maignan M, Savary D, Koch FX, Ruckly S, Durand M, Picard J, Escallier C, Chouquer R, Santre C, Minet C, Guergour D, Hammer L, Bouvaist H, Belle L, Adrie C, Payen JF, Carpentier F, Gueugniaud PY, Danel V, Timsit JF (2014) Impact of intra-arrest therapeutic hypothermia in outcomes of prehospital cardiac arrest: a randomized controlled trial. Intensive Care Med 40:1832-1842

15. Dankiewicz J, Nielsen N, Annborn M, Cronberg T, Erlinge D, Gasche Y, Hassager C, Kjaergaard J, Pellis T, Friberg H (2015) Survival in patients without acute ST elevation after cardiac arrest and association with early coronary angiography: a post hoc analysis from the TTM trial. Intensive Care Med 41:856-864

16. Dumas F, Bougouin W, Geri G, Lamhaut L, Rosencher J, Pène F, Chiche JD, Varenne O, Carli P, Jouven X, Mira JP, Spaulding C, Cariou A (2016) Emergency PCl in post-cardiac arrest patients without ST-segment elevation pattern: insights from the PROCAT II registry. JACC Cardiovasc Interv. doi: 10.1016/j.jcin.2016.02.001

17. Elmer J, Scutella M, Pullalarevu R, Wang B, Vaghasia N, Trzeciak S, RosarioRivera BL, Guyette FX, Rittenberger JC, Dezfulian C, Pittsburgh PostCardiac Arrest Service (PCAS) (2015) The association between hyperoxia and patient outcomes after cardiac arrest: analysis of a high-resolution database. Intensive Care Med 41:49-57

18. Daviaud F, Dumas F, Demars N, Geri G, Bouglé A, Morichau-Beauchant T, Nguyen YL, Bougouin W, Pène F, Charpentier J, Cariou A (2014) Blood glucose level and outcome after cardiac arrest: insights from a large registry in the hypothermia era. Intensive Care Med 40:855-862

19. Sandroni C, Cariou A, Cavallaro F, Cronberg T, Friberg H, Hoedemaekers C, Horn J, Nolan JP, Rossetti AO, Soar J (2014) Prognostication in comatose survivors of cardiac arrest: an advisory statement from the European Resuscitation Council and the European Society of Intensive Care Medicine. Intensive Care Med 40:1816-1831

20. Sivaraju A, Gilmore EJ, Wira CR, Stevens A, Rampal N, Moeller JJ, Greer DM, Hirsch LJ, Gaspard N (2015) Prognostication of post-cardiac arrest coma: early clinical and electroencephalographic predictors of outcome. Intensive Care Med 41:1264-1272

21. Sandroni C, Soar J, Friberg H (2016) Does this comatose survivor of cardiac arrest have a poor prognosis? Intensive Care Med 42:104-106 